\title{
The Main Burdens of Doing Business Perceived by Family-Owned Hospitality Enterprises in Slovakia
}

\author{
L'udmila Šmardová*, L'uboš Elexa**
}

\begin{abstract}
The main aim of the article is to identify the main burdens of doing business perceived by Slovak family owned hospitality businesses as well as to assess their view on the prospects for family businesses in Slovakia. The article analyzes primary data gained from an opinion survey conducted by means of a questionnaire in 2013. The business environment perception is evaluated according to the perception of certain external business environment indicators (conditions of doing business) depicted on the basis of the results of the pilot survey conducted in 2009 and the research carried out in 2010/2011. The results allowed us to identify the most discussed topics and burdens of doing business in tourism and hospitality in Slovakia.
\end{abstract}

Keywords: family business, hospitality, business environment, business conditions.

\section{Introduction}

The hospitality businesses provide the basic tourism services. Hence, their activities depend on the degree of the tourism development in a particular country as well as on the country's competitiveness as a tourism destination on the international tourism market. The enterprises have to provide competitive services in terms of both quality and price, which retrospectively influence the country's competitiveness as a final tourist destination. The provision of such services depends on the business conditions established by the state. The role of the state is essential, not only as a warrantor of systematic support, but also as a creator of favorable environment.

Slovakian tourism has not been one of the most profitable sectors of the national economy for a long time and it has declined since the global economic recession took place. The businesses perceive business conditions as much more difficult in the period of a significant decrease of their economic activity.

* L'udmila Šmardová, Ph.D., Faculty of Economics, Matej Bel University, Tajovskeho 10, 97590 Banska Bystrica, Slovakia, ludmila.smardova@umb.sk.

** Luboš Elexa, Ph.D., lubos.elexa@umb.sk. 
The aim of the article is to identify the main burdens of doing business perceived by Slovakian family owned hospitality businesses as well as to assess their view on the prospects for family businesses in Slovakia.

\section{Literature review}

There is much attention devoted to family business theory and practice in foreign literature. In spite of this fact, there is not a single definition of family business which is widely and exclusively applied to every conceivable area, such as to public and policy discussions, to legal regulations, as an eligibility criterion for support services, and to the provision of statistical data and academic research (Mandl, 2008, p. 7). Literature reviews on family business refer to the multitude of definitions. Sharma et al. (1996) and Chua et al. (1999) comprehensively reviewed literature and found 34 definitions. Birley (2001) also argued that in some countries the term family business is not used, nor it is understood (after: Getz, Carlsen and Morrison, 2003, p. 4). In family business analysis carried out by the Austrian Institute for SME Research on behalf of the European Commission, there were 90 different definitions identified in 33 European countries (Mandl, 2008).

Even though all those definitions are heterogeneous, still the specification of family business comes from common interaction of three elements: the family, the business and the ownership. Their intersection influences were illustrated by Tagiuri and Davis (1982) in the Three - Cycle Family Business Model (after: Davis, 2007, p. 5):

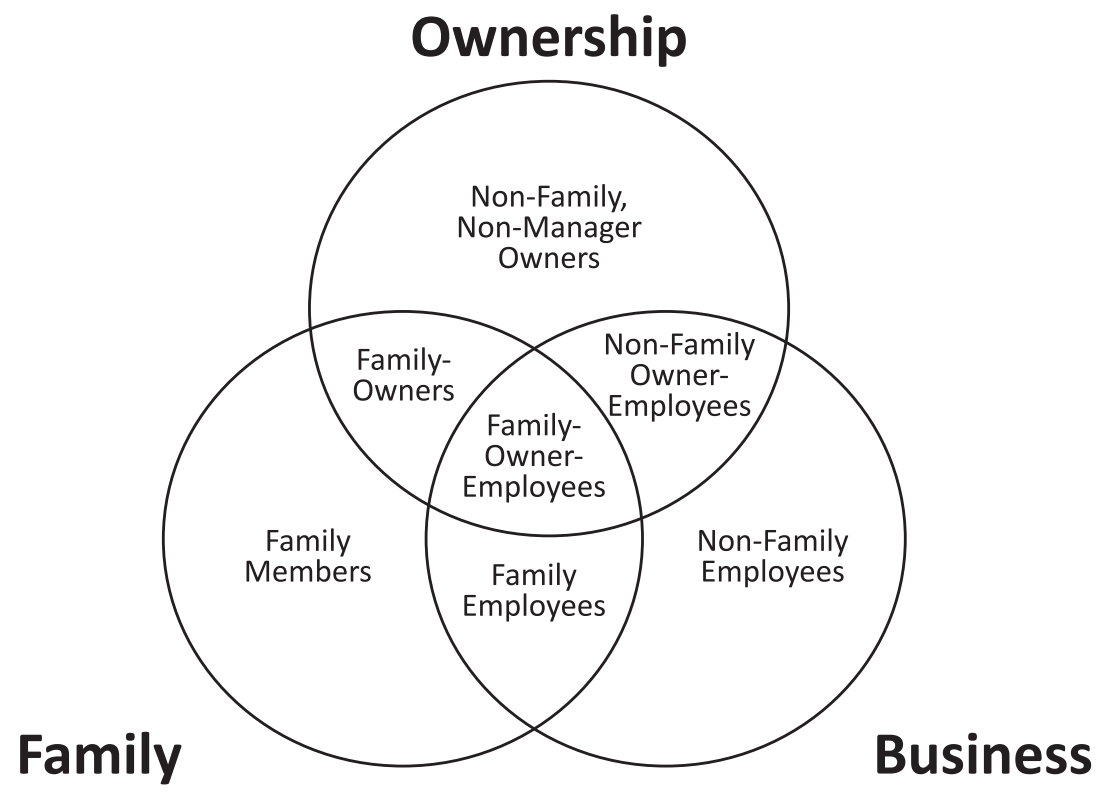

Figure 1. Three-cycle family business model Source: Davis (2007), p. 5. 
The model of Tagiuri and Davis (1982) defines seven categories of people with different interests within environment occupied by family, company and its owners. The importance of relations between family and entrepreneurship is stressed even by Harveston, Davis, and Lyden (1997), who mentioned that family enterprises' uniqueness is based on the fact that they represent a context (or an arena) in which two seemingly disparate social units (i.e., families and businesses) are highly integrated (Harveston et. al, 1997, p. 374).

Family businesses are frequently tied in literature to small companies. We have to point out that apart from family and business elements, ownership is also very important. Ownership creates the third cycle in the family business model. EU expert group for family businesses research specifies that ownership is key to the business life of the firm. It enables a clear distinction to be made between family and non-family businesses. Taking the 'ownership perspective' rather than the 'company size' perspective can help improve understanding of the phenomenon (European Commission, 2009). Ownership, on the other hand, significantly limits overall influence of family in strategic management and strategic decisions.

For the needs of corporate practice, McCabe (2012) recommends adding three more elements to Tagiuri and Davis Three - Cycle Family Business Model (1982) which are "divorce", "real estate" and "partnerships". He developed a new model, as he mentions "21st Century Client Relation Model (CRM) diagram is just beginning. Further additions can and should be made." (McCabe, 2012, p. 3).

Three - cycle family business model is the starting point for all experts examining different aspects of family business as well as trying to define it. Experts in the field use many different criteria to distinguish these businesses, such as percentage of ownership, strategic control, involvement of multiple generations, and the intention for the business to remain in the family (Astrachan and Shanker, 2006, p. 211). Astrachan and Shanker created a range of possible family business definitions from a broad, inclusive definition to a narrow and more exclusive one. The level of inclusiveness depends on the perceived degree of family involvement in the business (2003, p. 211).

Since this paper is focused on family businesses in Slovakia, which is an EU member country, we consider the definition of EU expert group as the most important one. However, just this one is recommended for all member countries in order to ensure comparability of research results within EU. According to this recommendation a firm, of any size, is a family business, if: (1) The majority of decision-making rights is in the possession of the natural person(s) who established the firm, or in the possession of the natural person(s) who has/have acquired the share capital of the firm, or in 
the possession of their spouses, parents, child or children's direct heirs. (2) The majority of decision-making rights are indirect or direct. (3) At least one representative of the family or kin is formally involved in the governance of the firm. (4) Listed companies meet the definition of family enterprise if the person who established or acquired the firm (share capital) or their families or descendants possess 25 per cent of the decision-making rights mandated by their share capital (EC, 2009).

Attention is devoted to family businesses because of their huge economic contribution, mainly in the form of added value and employment increase. Several studies have suggested that family enterprises are emerging as the central force driving economies in former socialist or so-called transition countries (Duh and Tominc, 2005; Pistrui et al., 1997; Poutziouris et al., 1997; Vadnjal, 2005, after: Duh, 2012, p. 210).

According to some available studies, the share of family businesses in overall employment equals and even exceeds $70 \%$ (Mandl, 2008). In Austria the share of family businesses in the number of all business entities accounts for more than $80 \%$ and they create $70-75 \%$ of all jobs (Mandl and Obenaus, 2008). Family businesses represent $91 \%$ of all businesses in Finland and 85 $\%$ in Spain. Employment created by family businesses reached about $40 \%$ (Family Business International, 2008). According to the analysis of EU expert group for family businesses, the share of family businesses in Slovakia is about $90 \%$, in Czech Republic $84 \%$, in Poland up to $75 \%$ and in Hungary about $70 \%$ (Mandl, 2008). The extent of family entrepreneurship in USA is very high and represents between 80 and $90 \%$, thus creating $62 \%$ jobs (Astrachan and Shanker, 2006). Annual contribution of family businesses to global gross domestic product is between 70 and $90 \%$ (Family Firm Institute Inc., 2013). Another mentioned asset of family entrepreneurship is the fact that they: reinvest profits responsibly preferring equity as opposed to debt financing., act as responsible owners because of their long-term strategy towards stakeholder interests, including employees, customers, shareholders, local communities; transmission of family values with a high sense of social responsibility; special concern for the local or regional base; natural incubators of an entrepreneurial culture, they foster the next generation of European entrepreneurs; stewards of social and economic capital from one generation to the next (EFB, 2013). Tourism as a sector is labor intensive and the success of businesses is derived from the quality of personnel. Getz and Carlsen mentioned that "tourism offers many opportunities for family business, often embodying direct host - guest interaction in the family home or property. They are often vital to customer satisfaction and to destination and community development" (2005, p. 237). 
Literature specifies mostly family and its members' motivation to run a business, inner organization structure and structure of management, etc. Chen and Elston (2013) in the study of small restaurant owners emphasized that entrepreneurship literature identifies critical factors of running business not only on the micro-level, or personal level of business, but also on the macro-environment level (Figure 2).

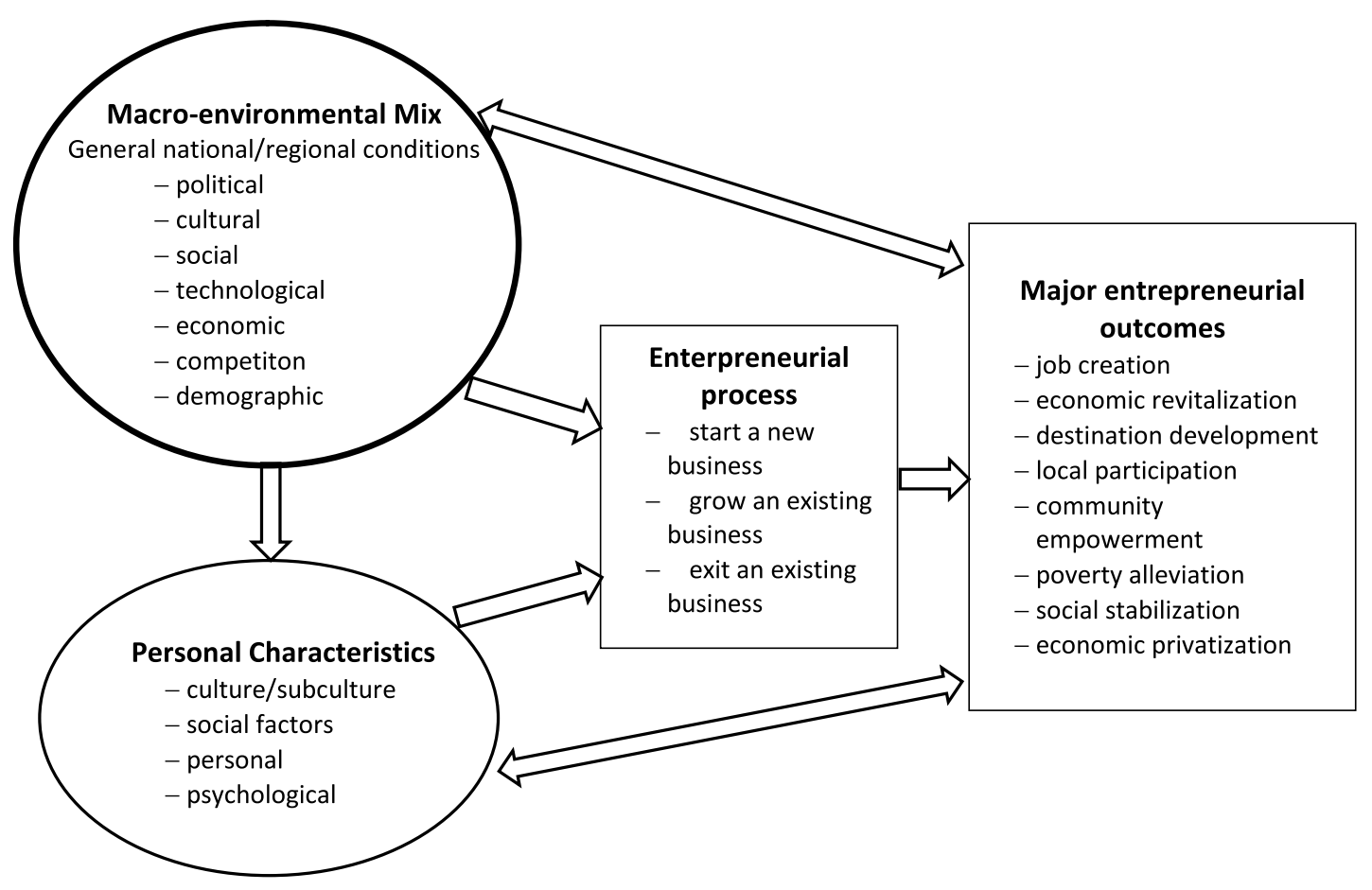

Figure 2. Critical factors influencing entrepreneurial behavior Source: Chen \& Elston (2013), p. 296.

Macro-environment forms external conditions for doing business which businesses are not able to affect. Enterprises can only expect impacts of changes in social, economic, environmental and legislative conditions. Special attention to business environment conditions is paid by European Union. Create an environment in which entrepreneurs and family businesses can thrive and entrepreneurship is rewarded (Communication, 2008, p. 4) is the first of ten principles of a "Small Business Act" for Europe. There are numerous questionable aspects of business environment in tourism which arise mainly from particularities of this sector. Policy regarding economic development generally favors tourism and hospitality investments, at least in designated areas - typically those peripheral to urban and economic centers. Ironically, the industry is also highly regulated and taxed (Getz et. al, 2004, p. 13). Mendonsa (1983, after: Getz and Carlsen, 2000, p. 549) discovered 
that in Portugal only family tourism businesses with capital could benefit, but others were unable to do so.

We consider just external conditions for doing business to be crucial in business development for this moment. Companies are not able to influence them and their changes create opportunities or threats for businesses. Family businesses in market and mixed economies prevail in number and share. Some of the studies point at the fact that family businesses participate mainly in labor intensive sectors, including tourism (Mandl, 2008). There is not enough attention devoted to external conditions for doing business and those influence even the inner structure and personal ties in family business. For example, family members' employment is influenced by labor law and the size of social contribution. The size of tax burden influences the family income and consequently its motivation to run a business. Family entrepreneurship is an exceptionally important aspect of tourism development. It contributes to better quality of services and destinations development. Afterwards, frequent changes in external environment, which negatively affect approach to family entrepreneurship, may indirectly limit development of tourism.

\section{Research methods}

The main aim of the article is to identify the main burdens of doing business perceived by Slovakian family owned hospitality businesses as well as to assess their view on the prospects of family businesses in Slovakia.

Slovakian hospitality sector has not been one of the most profitable sectors of national economy for a long time and it has declined since 2008 when the economic recession started. The research connects two important aspects of tourism development in Slovakia:

- importance of family businesses providing high quality hospitality services, which are more competitive and make Slovakia more attractive as tourist destination; those businesses are more responsible and stable in doing business and contribute to economic growth; and

- conditions for doing business created by the state, which significantly affect economic activity. Businesses are not able to influence those conditions. Identification of main burdens in doing business helps to identify some of the reasons of slow economic development of hospitality sector perceived by family businesses in Slovakia. The research revolves around the problem of whether providing hospitality services is perceived by family businesses to be prospective in current business environment conditions. Creating favorable business environment is important not only in the time of crisis. But in times of economic fall businesses are more sensitive and expect effective regulations which support their economic activity. 
The article presents certain results of business environment evaluation in Slovakia, based on the perception of certain business environment indicators. The research is based on the primary data gained from an opinion survey conducted by means of a questionnaire in 2013. It focused on the identification of the main burdens in doing business in Slovakia as well as their prospects for doing business in certain business environment. The survey was mainly focused on the external conditions.

The business environment perception is evaluated according to the perception of certain indicators' categories (Table 1).

Table 1. Criteria of the business environment's evaluation

\begin{tabular}{ll}
\hline Category of doing business indicators & Criteria \\
\hline \multirow{2}{*}{ Meeting legal and administrative conditions } & Trade Office \\
& Tax Office \\
& Social Insurance Agency \\
& Health Insurance Agency \\
& Labour Code \\
& Regional public health Authority \\
\hline & Income tax \\
& Value added tax (VAT) \\
Taxes & Vehicle tax \\
& Immovable property tax \\
& Other local taxes (fees) \\
& Excise taxes \\
\hline \multirow{2}{*}{ Tax system } & Total tax rate \\
& Administrative severity \\
\hline & Time requirements \\
\hline Mocial payments system & Total rate \\
\hline Tourism development & Administrative severity \\
\hline
\end{tabular}

Criteria (indicators) were depicted based on the results of the pilot research carried out in 2009 and the research conducted in 2010/2011 which identified the most discussed topics and burdens in doing business in tourism in Slovakia. Business entities are very sensitive to changes of business conditions in Slovakia, especially since 2009 when the economic downturn in Slovak tourism started. Since such topic is very broad, we will not focus on the processes connected with starting up and terminating business activity, but on perception of conditions considered vital when running a business. Criteria are completed by changes of business environment in 2013. The 
research was conducted among enterprises providing hospitality services in Slovakia. According to the NACE rev. 2 classifications they are classified in the section I - Accommodation and food service activities. We excluded entities providing services in category 155.90 - Other accommodation (longer term accommodation for students, workers and similar individuals), which we do not consider to be provided in tourism.

We processed the collected primary data using mathematical-statistical methods. Qualitative variables of research are selected conditions of doing business - criteria of the business environment evaluation. We mainly use the methods of descriptive statistics - absolute and relative frequencies expressed as percentage, to identify the burdens of doing business perceived by the majority (more than $50 \%$ ) of observed family business entities.

In addition to the evaluation of analyzed business conditions, we investigate if the family businesses perceive doing business in current conditions to be prospective.

We formulated the hypothesis based on the results of preliminary research and secondary data showing slow economic development of hospitality sector in Slovakia. We expect that the majority of Slovakian family businesses providing hospitality services perceive doing business in hospitality as non-prospective if the current conditions in Slovakia remain the same. The hypothesis will be verified processing data by basic statistical method of descriptive statistics using relative frequencies expressed in percentage. We use the theoretical methods of abstraction, induction and comparison to process the results of the analyses into consequences at the end.

The sample was created by 200 family enterprises. Stemming from EU expert group estimation, according to which up to $95 \%$ of all business entities are family businesses (Mandl, 2008), we consider our research to be representative. Currently, there are no statistical data about family business numbers in hospitality sector in Slovakia and its characteristics. Based on the composition of statistical population (all hospitality businesses in tourism) in Slovakia, research sample is representative as to the size and legal form (Table 2, Table 3). 
Table 2. Slovakian tourism hospitality businesses in 2013 (based on Nace rev. 2 classification Section I excluding category 55.9) according to the business size

\begin{tabular}{|c|c|c|c|c|c|}
\hline $\begin{array}{l}\text { Business size (number } \\
\text { of employees) }\end{array}$ & $\begin{array}{l}\text { Micro } \\
(0-9)\end{array}$ & $\begin{array}{c}\text { Small (10 } \\
-49)\end{array}$ & $\begin{array}{l}\text { Medium } \\
(50-249)\end{array}$ & $\begin{array}{l}\text { Large (above } \\
249)\end{array}$ & Total \\
\hline Absolute number & 17303 & 990 & 70 & 4 & 18367 \\
\hline $\begin{array}{l}\text { Percentage share of } \\
\text { businesses }\end{array}$ & 94.21 & 5.39 & 0.38 & 0.02 & 100.00 \\
\hline
\end{tabular}

Source: Own processing based on Statistical Office of Slovak Republic (2013) and survey results (2013).

There are approximately $99 \%$ of tourism hospitality businesses in the category of micro and small businesses in Slovakia. In this categories there were also $99 \%$ of surveyed businesses (180 entities are micro-businesses and 18 businesses are small). 2 surveyed subjects (1\%) were medium size.

Tabe 3. Slovakian tourism hospitality businesses in 2013 (based on Nace rev. 2 classification Section I excluding category 55.9) according to the legal form

\begin{tabular}{lcccc}
\hline Legal form of business & sole proprietor & Plc. & other & total \\
\hline Absolute number of businesses & 12390 & 5651 & 326 & 18367 \\
Percentage share of businesses & 67.46 & 30.77 & 1.77 & 100.00 \\
\hline
\end{tabular}

Source: Own processing based on Statistical Office of Slovak Republic (2013) and survey results (2013).

Most hospitality businesses in tourism are sole-proprietors $67.46 \%$. The second most common legal form is private limited company with almost $31 \%$ share. The research sample covered 114 (57\%) sole-proprietors and 83 (41.5 $\%)$ private limited companies. The rest -2 subjects (1.5\%) were in the legal form of stock company.

We used also secondary data of the turnover and the employment to identify the development of economic activity in hospitality sector in Slovakia. The data were gained from the statistical information published by the national statistical bureau. We are using the mathematical-statistical methods of processing, namely basis and chain indexes lined up in time series since 2006 until 2012.

\section{Analysis of family businesses' burdens and perspective in hospitality sector}

All surveyed companies are considered to be family businesses according to definition of the European Union. In most interviewed businesses 
management is still in first family generation (77\%). The second generation took over in case of $22 \%$. Just $1 \%$ of all examined subjects were run by third generations. These results are due to historical aspects and shorter tradition in running a business in Slovakia, which has been possible just since 1989. In these family businesses we can find spouses as the most frequent employees $-46.5 \%$ and their direct descendants (40\%). Most companies (54.5\%) employ family members belonging to two generations. $8.5 \%$ of family members worked in lower management (shift leaders), 31 \% in middle management (department managers), $17.5 \%$ in top management (directors). But it is common for family members employed in family businesses not to be involved in management. This is the case of $43 \%$ family businesses. Due to the objective of our study we will not focus on family business structure in detail anymore.

We consider the analysis of conditions for doing business to be very important, mainly because of rapid decline of economic activity of Slovakian hospitality businesses since 2008.

Slovakian catering and hospitality businesses reached the highest turnover in 2008. It was $22.8 \%$ lower in 2009 compared to previous year. This was a critical fall for doing business in Slovakia because the revenues had slowly been rising till 2008 (Table 4.).

Table 4. Turnover of the hospitality businesses in Slovakia in 2006-2012

\begin{tabular}{ccccc}
\hline Year & $\begin{array}{c}\text { Turnover (in thousands } \\
€ \text { ) }\end{array}$ & Annual Change & $\begin{array}{c}\text { Chain index of } \\
\text { turnover }\end{array}$ & $\begin{array}{c}\text { Basis index of } \\
\text { turnover }\end{array}$ \\
\hline 2006 & 1379008 & - & 100,0 & 100.0 \\
2007 & 1433778 & 54770 & 104,0 & 104.0 \\
2008 & 1518700 & 84922 & 105,9 & 110.1 \\
2009 & 1172600 & -346100 & 77,2 & 85.0 \\
2010 & 1092800 & -79800 & 93,2 & 79.3 \\
2011 & 1105000 & 12200 & 101,1 & 80.1 \\
2012 & 1134200 & 29200 & 102,6 & 82.3 \\
\hline
\end{tabular}

Source: Processing based on the data of the Statistical Office of Slovak Republic (2013).

The turnover had fallen by additional $6.8 \%$ in 2010 compared to 2009 . This economic indicator had decreased to about $28 \%$ during the economic fall (during 2009 and 2010) even though the rate of this decline slowed down in 2010. We can see that even though the turnover has slowly increased since 2011, top level was nearly $18 \%$ lower in 2012 compared to 2006 and about $25 \%$ lower compared to the most successful year 2008.

Newly created jobs in catering and hospitality sector have been decreasing in Slovak Republic since 2008 (Table 5.). 
Table 5. Employment in hospitality businesses in Slovakia in 2006-2012

\begin{tabular}{|c|c|c|c|c|c|c|}
\hline \multirow[t]{2}{*}{ Year } & \multicolumn{2}{|c|}{$\begin{array}{c}\text { Employment } \\
\text { (in thousands of jobs) }\end{array}$} & \multicolumn{4}{|c|}{ Employment in observed sector } \\
\hline & State & $\begin{array}{l}\text { Observed } \\
\text { sector }\end{array}$ & $\begin{array}{c}\text { annual change } \\
\text { in number of } \\
\text { jobs }\end{array}$ & $\begin{array}{l}\text { chain } \\
\text { index }\end{array}$ & $\begin{array}{l}\text { basis } \\
\text { index }\end{array}$ & $\begin{array}{c}\% \text { share } \\
\text { on state } \\
\text { employment }\end{array}$ \\
\hline 2006 & 1330.5 & 48.2 & - & 100.0 & 100.0 & 3.62 \\
\hline 2007 & 1384.6 & 50.9 & 2702 & 105.6 & 105.6 & 3.68 \\
\hline 2008 & 1425.8 & 50.0 & -887 & 98.3 & 103.8 & 3.51 \\
\hline 2009 & 1282.1 & 41.2 & -8775 & 82.5 & 85.6 & 3.22 \\
\hline 2010 & 1229.9 & 38.2 & -3024 & 92.7 & 79.3 & 3.11 \\
\hline 2011 & 1257.4 & 38.1 & -126 & 99.7 & 79.0 & 3.03 \\
\hline 2012 & 1255.2 & 38.5 & 366 & 100.1 & 79.8 & 3.06 \\
\hline
\end{tabular}

Source: Processing based on the data of the Statistical Office of Slovak Republic (2013).

Employment decreased by $17.5 \%$ in 2009 - the year of the most significant turnover fall - compared to the previous year. The fall continued during 2010 when the employment decreased by additional $7.3 \%$ compared to 2009. There was about $25 \%$ decrease during the economic downturn since 2007 to 2011, even though the employment fall has slowed down in 2010. The observed sector share in the national employment was about $3.68 \%$ in the year of the highest employment (2007) and it fell to $3.03 \%$ in 2011.

\section{Perception of administrative burden in running a business}

In our research we examined how family businesses evaluate overall administrative burden they are suffering from. $90.5 \%$ of family businesses in hospitality sector consider the operation of hospitality business to be administratively demanding and conversely, fewer than $10 \%$ think that business processes are not demanding. We analyzed how businesses evaluate necessary administration processes they are supposed to handle with the most important authorities in business sector. Among the most important authorities we rank tax office, trade office, regional public health authority, social insurance agency, health insurance agency and we also included there compliance with labor code (Table 6). 
Table 6. Subjective perception of administrative burden

\begin{tabular}{lcc}
\hline Perception of administrative burden & $\begin{array}{c}\text { Absolute } \\
\text { numerous }\end{array}$ & $\begin{array}{c}\text { Percentage } \\
\text { share }\end{array}$ \\
\hline $\begin{array}{l}\text { Trade Office } \\
\text { Low }\end{array}$ & 24 & 12,0 \\
Average & 108 & 54,0 \\
High & 68 & 34,0 \\
Tax Office & & \\
$\quad$ Low & 5 & 2,5 \\
Average & 62 & 31,0 \\
High & 133 & 66,5 \\
Social insurance agency & & \\
Low & 7 & 3,5 \\
Average & 115 & 57,5 \\
High & 78 & 39,0 \\
Health insurance agency & & \\
Low & 11 & 5,5 \\
Average & 119 & 59,5 \\
High & 70 & 35,0 \\
Regional public health authority & & \\
Low & 7 & 3,5 \\
Average & 98 & 49,0 \\
High & 95 & 47,5 \\
Labor Code and Labor Law & & \\
Low & 51 & 2,5 \\
Average & 114 & 40,5 \\
High & 57,0 \\
\hline
\end{tabular}

As the most negative perception of administrative burden came the answers of family businesses in the field of taxation. $66.5 \%$ of family businesses feel that the most arduous task is to deal with tax offices. $57 \%$ of businesses thought that even labor code and labor law agenda is demanding. This negative evaluation is probably due to significant changes in legislation since 2013 which influenced primarily the business of small companies. Changes in this area are very frequent and this can also lead to overall negative perception. At the same time they caused huge administrative burden and through this they negatively affected day-to-day business activities.

\section{Perception of particular taxes}

Slovakian tax system consists of direct and indirect taxes. Direct taxes are imposed on profit of individuals (personal income tax, corporate income tax), or on property, such as local taxes and community charges, while indirect taxes are imposed on consumption in general. For our research we divided Slovakian taxes in six groups as followed: profit tax (including income tax of 
self-employed person), Value Added Tax (VAT), Motor vehicle tax, Immovable property tax, accommodation tax (overnight tax) other communities' taxes (charges) and excise taxes (Table 7). Groups are selected according to results of the pilot research and along the requirements of our research as well as in line with the extensiveness of a specific topic.

Table 7. Subjective perception of particular taxes` framework

\begin{tabular}{|c|c|c|}
\hline Perception & Absolute numbers & $\begin{array}{c}\text { Percentage } \\
\text { share }\end{array}$ \\
\hline \multicolumn{3}{|l|}{ Profit tax } \\
\hline Positive & 35 & 17.5 \\
\hline Neutral & 101 & 50.5 \\
\hline Negative & 64 & 32.0 \\
\hline \multicolumn{3}{|c|}{ Value Added Tax } \\
\hline Positive & 39 & 19.5 \\
\hline Neutral & 100 & 50.0 \\
\hline Negative & 61 & 30.5 \\
\hline \multicolumn{3}{|c|}{ Motor vehicle tax } \\
\hline Positive & 15 & 7.5 \\
\hline Neutral & 120 & 60.0 \\
\hline Negative & 65 & 32.5 \\
\hline \multicolumn{3}{|c|}{ Immovable property tax } \\
\hline Positive & 11 & 5.5 \\
\hline Neutral & 110 & 55.0 \\
\hline Negative & 79 & 39.5 \\
\hline \multicolumn{3}{|c|}{ Accommodation tax } \\
\hline Positive & 16 & 8.0 \\
\hline Neutral & 102 & 51.0 \\
\hline Negative & 82 & 41.0 \\
\hline \multicolumn{3}{|c|}{ Other community taxies (charges) } \\
\hline Positive & 18 & 9.0 \\
\hline Neutral & 137 & 68.5 \\
\hline Negative & 45 & 22.5 \\
\hline \multicolumn{3}{|l|}{ Excise taxes } \\
\hline Positive & 34 & 17.0 \\
\hline Neutral & 105 & 52.5 \\
\hline Negative & 61 & 30.5 \\
\hline
\end{tabular}

No evaluation of the observed group of taxes has been unambiguously positive. The reason is that all taxes or groups are perceived by less than one fifth of businesses to be positive. Positive evaluation (on questionnaire explained as perceived to be effective) has not been expected due to the fact that taxes are the most frequently mentioned burden of business environment in every field of national economy in most societies, especially in Slovakia. 
The majority of observed businesses accept (perceive as neutral) all analyzed taxes, even if there is a significant share of negative perception.

Hospitality businesses are not entities taxable with VAT, excise taxes or accommodation tax. The subjects are not administratively burdened only with excise taxes. VAT and accommodation tax requires special administration and evidence. The indirect taxes rates' height influences the price of production inputs (excise taxes), which is reflected in business costs and final consumption price (VAT and accommodation tax) of hospitality services. We can consider this to be the main reason of negative subjective perception of indirect taxes.

No particular tax was evaluated negatively (perceived to be ineffective). But the tax system as such is evaluated negatively. The evaluation of tax system in general is based on the following three criteria: total tax rate, administrative severity, time severity based on legislative changes and procedures required (Table 8 ). The majority of family businesses perceived all aspects of tax system to be negative.

Table 8. Subjective perception of tax system

\begin{tabular}{lcc}
\hline Perception & $\begin{array}{c}\text { Absolute } \\
\text { numbers }\end{array}$ & $\begin{array}{c}\text { Percentage } \\
\text { share }\end{array}$ \\
\hline Total tax rate & 0 & 0.0 \\
$\quad$ Low & 44 & 22.0 \\
$\quad$ Average & 156 & 78.0 \\
$\quad$ High & & \\
Administrative severity & 1 & 0.5 \\
$\quad$ Low & 77 & 38.5 \\
$\quad$ Average & 122 & 61.0 \\
High & & \\
Time severity sequent to legislation and procedures & & 1.0 \\
required & 2 & 37.0 \\
$\quad$ Low & 74 & 62.0 \\
$\quad$ Average & 124 & \\
$\quad$ High & & \\
\hline
\end{tabular}

When analyzing the tax system evaluation it is necessary to mention the uniqueness of Slovakian tax system. There was an extensive tax system and framework reform implemented in Slovakia in 2004. It had introduced a $19 \%$ flat tax (constant marginal tax rate applied on individual and corporate income tax as well as VAT) which clarified the Slovakian tax system. VAT rate has changed in some ways e.g. it has defined the groups of goods allowed to be taxable by lower rate such as pharmaceuticals and some medical goods, books and some "home produced" agricultural goods, since the tax reform implementation. The majority of the goods remained taxed with the basic 
tax rate, which increased from $19 \%$ to $20 \%$ in 2011, based on the temporary arrangements of VAT law in charge. This increase of the tax rate was explained as a tool for tax revenues increase and it is valid until the last calendar day of the year when European Statistical Office publishes the data indicating the budget deficit of Slovakian Republic to be lower than $3 \%$ (Act No. 222/2004 Coll. On Value Added Tax as amended by Act No. 490/2010 Coll). Constant marginal tax rate applied on the individual and corporate income tax remained at the level of $19 \%$ till 2012 (Act No. 595/2003 Coll. Income Tax Act). The original unified flat tax rate of $19 \%$ is valid only for incomes of the entrepreneurs acting as natural entities and for natural entities with the annual income of up to $34402 €$. The income of natural entities (including entrepreneurs) exceeding the mentioned amount is taxed with the rate of 23 \% since 2013 (Act No. 395/2012 Coll.). Corporate profit tax increases to $23 \%$. With the system changes we can conclude the end of flat tax in Slovakia. This fact can influence the perception of administrative severity of tax system and can lead to negative business perception of business environment. It is only the beginning of tax rate changes and the impacts will probably be felt after the tax period of 2013 (at the beginning of 2014). We analyzed businesses' perception of flat tax and its changes (Table 9).

Table 9. Subjective perception of flat tax and its changes

\begin{tabular}{lcc}
\hline Perception & $\begin{array}{c}\text { Absolute } \\
\text { numbers }\end{array}$ & $\begin{array}{c}\text { Percentage } \\
\text { share }\end{array}$ \\
\hline Flat income tax (19\%) implementation in 2004 & 115 & 57.5 \\
$\quad$ Positive & 67 & 33.5 \\
$\quad$ Neutral & 18 & 9.0 \\
$\quad$ Negative & 111 & 55.5 \\
Flat VAT tax (19\%) implementation in 2004 & 70 & 35.0 \\
$\quad$ Positive & 19 & 9.5 \\
$\quad$ Neutral & & \\
Negative & 11 & 5.5 \\
Corporate income tax increase on 23\% since 2013 & 61 & 30.5 \\
$\quad$ Positive & 128 & 64.0 \\
$\quad$ Neutral & & \\
Negative & & \\
Natural person tax rate differentiation on 23 \%, 19\% rate & 17 & 8.5 \\
since 2013 & 60 & 30.0 \\
Positive & 123 & 61.5 \\
$\quad$ Neutral & & \\
$\quad$ Negative & & \\
\hline
\end{tabular}

Flat income tax is perceived to be positive by the majority of entities (57.5\%) as well as flat VAT tax (55.5\%) Negative perception was provided 
by just about $9 \%$ of businesses. The flat VAT caused increase of VAT rate of accommodation services (services were imposed the reduced rate of 6 $\%$ before 2004). Despite this fact flat VAT rate was evaluated as positive. More than $60 \%$ of businesses perceive the end of flat tax connected with increase of income tax rates as well as administrative severity to be negative. Frequent changes of vital business conditions cause problems especially to small tourism businesses, where all administrative procedures burden the owner, the entrepreneur, who is usually responsible for all administration.

\section{Perception of social contribution system}

After questioning businesses with open-ended questions we found out that they consider social contributions to be the most serious burden $(81 \%$ of businesses). This topic is frequently discussed in all industries and sectors, but in labor intensive sectors all negative changes are perceived even more sensitively. We evaluated the social contribution system in an identical way as tax system concentrating on the following three criteria: total rate, administrative severity, time severity (Table 10).

Table 10. Subjective perception of social payment system

\begin{tabular}{lcc}
\hline Perception & $\begin{array}{c}\text { Absolute } \\
\text { numerous }\end{array}$ & $\begin{array}{c}\text { Percentage } \\
\text { share }\end{array}$ \\
\hline Total rate & & \\
$\quad$ Low & 1 & 0.5 \\
$\quad$ Average & 37 & 18.5 \\
$\quad$ High & 162 & 81.0 \\
Administrative severity & & \\
$\quad$ Low & 4 & 2.0 \\
$\quad$ Average & 86 & 43.0 \\
$\quad$ High & 110 & 55.0 \\
Time severity sequent to legislation and procedures & & \\
required & & 1.5 \\
$\quad$ Low & 3 & 36.0 \\
$\quad$ Average & 72 & 62.5 \\
$\quad$ High & 125 & \\
\hline
\end{tabular}

All aspects are evaluated negatively. It might be caused by frequent changes with negative impacts mostly in the area of personal costs increase.

In Slovakia there is practically no legislation specifically oriented on family businesses. Therefore, when employing family members all companies are looking for the most effective available forms. One of them was utilization of a specific legal contract form based on mutual consent. Those contracts for work were not a part of full-time employment and were 
meant to ensure occasional jobs or bring specific result. Even it is true that they were supposed to be applied only on seasonal (occasional) activities or irregular work, family businesses used them more frequently because of their lower social contribution. However, since 2013 all those payments went up from $1.05 \%$ up to $48.6 \%$ in case of some employees with regular income. Social contribution in such contracts for work equalized the level of full-time contracts. We are not going deep into details in description, but finally all those legislation changes caused fundamental increase of personnel costs when employing seasonal workers as well as family members who previously could legally work and support family businesses by offering lower labor costs. Seasonal workers are especially important for companies providing services in tourism. Changes in social contributions were negatively perceived by 73.5 $\%$ of family businesses, $24.5 \%$ of them had neutral approach and just $2 \%$ positively evaluated the increase of social contributions. $34.5 \%$ of companies were forced to terminate contracts with some of their employees and $23 \%$ of them claimed they experienced significant increase of labor costs. Such extent of legislation changes that were hostile towards business entities may lead to a downturn of economic activities due to unfavorable labor cost changes, and eventually wind down the business. Another possibility may be the increase of shadow economy, illegal employment with an effort to cut down personnel costs to a minimum level.

\section{Tourism development}

Tourism is not one of developed sectors of Slovakian economy. On the other hand, it has been enjoying great attention and hospitality businesses are starting to perceive that they are not isolated subjects and for their individual success the whole system should be effective as well. They perceive promotion of tourist destination as an external condition for doing business. At the same time they started to consider activities of destination management organizations (DMO) to be an important part of tourism development. Those activities have been regulated in legislation only since the end of $2011.78 \%$ of surveyed family businesses are not able to evaluate activities of DMO in destination of their business. Only $6.5 \%$ of them positively evaluate DMO activities. This is attributed to a short history of such organizations in Slovakia. Only $13.5 \%$ of hospitality businesses are voluntary members of DMO.

Broader aspects of destination's development are not considered to be a barrier within external conditions. On the other hand, hospitality businesses still consider other aspects of external environment (which we have previously analyzed) to be more important. 


\section{Prospects of family businesses in hospitality}

We have examined two aspects of family businesses prospects among hospitality companies in Slovakia. Those were the prospects of family entrepreneurship as a source of family income and the prospects of entrepreneurship as such when business conditions in the future do not change.

Table 11. Perception of prospects in doing business

\begin{tabular}{lcc}
\hline Perception of prospects in current conditions of & $\begin{array}{c}\text { Absolute } \\
\text { numbers }\end{array}$ & $\begin{array}{c}\text { Percentage } \\
\text { share }\end{array}$ \\
\hline Doing business in hospitality & 52 & 26.0 \\
$\quad$ Prospective & 56 & 38.0 \\
$\quad$ Not able to evaluate the current situation & 92 & 46.0 \\
$\quad$ Non-prospective & & \\
Doing family business in hospitality & 72 & 36.0 \\
$\quad$ Prospective & 38 & 19.0 \\
$\quad$ Not able to evaluate the current situation & 90 & 45.0 \\
$\quad$ Non-prospective & & \\
\hline
\end{tabular}

Most of the observed businesses - $46.0 \%$, perceive doing business in catering and hospitality as non-prospective if the current conditions in Slovakia remain the same. Almost the same perception is shown about doing family business as perspective source of family incomes, $45 \%$ perceive family business as non-prospective in current external conditions. Only almost one third $-26.0 \%$ of them consider the hospitality to be a booming sector and 36 $\%$ consider doing business in hospitality to be a prospective source of family incomes in the future if current conditions remain unchanged. Some family businesses are not able to evaluate the current situation and the future of family business in hospitality. Based on this result we are not able to prove the hypothesis that the majority of Slovakian family owned businesses providing hospitality services perceive doing business in hospitality as non-prospective if the current conditions in Slovakia remain the same. Even though there is a significant share of non - prospective perceptions of doing business in future ( $46 \%$ ), this opinion is not shared by the majority (more than $50 \%$ ) of observed entities.

\section{Discussion}

The main barriers of doing business are included in the intersection of the legislative, political and economic business environment. They are identified in line with certain category of indicators and negative perception of criteria based on the methodology of the research. Most of the observed indicators were directly indicated as a burden by the enterprises. We evaluated those business environment indicators which are perceived as negative by the 
majority of the observed business entities (more than $50 \%$ share of all entities included in the survey) to be the burden of doing business. In case the subject did not evaluate the criterion we understand this approach as not being a burden. We consider the following to be the main burdens of doing business perceived by family hospitality business:

- administrative severity of meeting of all legal conditions perceived by $90.5 \%$ of observed family businesses;

- difficulties connected with tax office agenda, which are negatively perceived by $66.5 \%$ of investigated companies and caused by frequent changes in this area;

- tax system. Total rate of taxation is considered to be too high by $78 \%$ of companies involved, while all taxes within tax system were evaluated neutrally and companies accept their necessity. Higher administrative burden within tax system is perceived by $61 \%$ of family businesses, including its time consuming intensity which was declared by $62 \%$ of businesses (also they are caused by frequent changes in legislation, mainly when speaking about income taxes);

- negatively appraised labor legislation and its agenda, given by $57 \%$ of businesses;

- high social contribution, which was stated by $81 \%$ of subjects involved. We consider this is the result of changes valid since 2013, which made administration burden to be higher. As a barrier it is understood in 55 $\%$ of family businesses and as time consuming it was answered in $62,5 \%$ of acquired questionnaires.

Based on the identification of the main barriers of family businesses' development in hospitality sector in Slovakia we can state that attention given to external conditions of doing business in Slovakia is very important nowadays. Family businesses are considerably numerous when comparing them with all business entities, they are significantly contributing to employment, creation of economic and social values. Situation in tourism in Slovakia is quite serious. Several authors are engaged in this topic, dealing with the current system crisis in tourism (Malachovský, 2012), attractiveness of Slovakia for foreign visitors (Pompurová, 2013), as well as necessary increase of quality in provided services (Kučerová, Marčeková and Nedelová, 2010), or planning of tourism development (Kučerová and Makovník, 2009). Special attention is often paid to general external business environment conditions in Slovakia (Klementová, 2008; Hvolková, 2013). But also examination of external conditions for doing business, especially in tourism and creation of favorable business environment, should become one of the priorities. Only in developed environment the companies could focus on their own inner development and family businesses have positive effects on economy, as several international experts mentioned before. It is also family entrepreneurship in tourism which 
should be in the center of research attention in tourism, mainly in connection to specific Slovakian legislation and its frequent changes.

\section{Conclusion}

The article focused on business environment evaluation based on perception of family owned hospitality businesses. The aim of the article was to identify the main burdens of doing business perceived by Slovakian family owned hospitality businesses as well as to assess their view on prospects of family businesses in Slovakia.

Family owned businesses in Slovakia are more sensitive to changes of external business environment, namely indicators in the intersection of legislative, economic and political environment. Dealing with business conditions hinders internal development of family businesses as well as tourism development in Slovakia. Most discussed business conditions are characteristics of tax and social payment system which lead to high administrative, financial and time severity of doing business in hospitality. We observe a critical situation in Slovakia. A large share of Slovakian family businesses (46\%) in hospitality evaluate doing business in tourism in current conditions as non-prospective. It is important to pay higher attention to Slovakian business environment improvement in research and practice.

The research results are a part of the implementation of the project "VEGA 1/0810/13 Preconditions for concept application of the socially responsible behavior in tourism in Slovak Republic" which is supported by the scientific grant agency of Ministry of Education, Science, Research and Sport of the Slovak Republic.

\section{References}

Act No. 289/1995 Coll. on Value Added Tax (Slovak Republic)

Act No. 595/2003 Coll. Income Tax Act (Slovak Republic)

Act No. 222/2004 Coll. on Value Added Tax (Slovak Republic)

Act No. 222/2004 Coll. on Value Added Tax as amended by Act No. 490/2010 Coll. (Slovak Republic)

Act No. 395/2012 Coll. (Slovak Republic)

Astrachan, J. H., and Shanker, M.C. (2006). Family businesses' contribution to the U.S. economy: a closer look. Handbook of Research on Family Business, 211-219. doi:10.4337/9781847204394.00011.

Communication. (2008). Communication from the Commission to the Council, the European Parliament, the European Economic and Social Committee and the Committee of the Regions: Implementing the Lisbon Community Programme for Growth and Jobs - Transfer of Business, Continuity 
through a new beginning. Retrieved from http://eur-lex.europa.eu/ LexUriServ/LexUriServ.do?uri=COM:2008:0394:FIN:EN:PDF.

Davis, J. A. (2007). Fundamentals of Family Business System Governance. Harvard Business School Background Note 807-019, August 2006. (Revised July 2007).

Duh, M. (2012). Family businesses: the extensiveness of succession problems and possible solutions. Entrepreneurship - Gender, Geographies and Social Context, 210 -234. Retrieved from http://www.intechopen. com/books/entrepreneurship-gendergeographies- and-social-context/ family-businesses-the-extensiveness-of-succession-problems-andpossiblesolutions.

European Family Business. (2013). Family in Business for the long-term. Retrieved from http://www.europeanfamilybusinesses.eu/documents/ docs/EFB\%20Brochure.pdf.

Family Business International. (2008). Family Business International Monitor. Retrieved from http://www.fbn-ukraine.com/downloads/monitor2008. pdf.

Family Firm Institute Inc. (2013). Global Data Points. Retrieved from http:// www.ffi.org/?page=globaldatapoints.

European Commission. (2009). Final Report of the EU Expert Group, Overview of Family-Business-Relevant Issues: Research, Networks, Policy Measures and Existing Studies. Retrieved August 1, 2013, from http://ec.europa.eu/ enterprise/policies/sme/promoting-entrepreneurship/family-business/ family_business_expert_group_report_en.pdf.

Getz, D., Carlsen, J. (2000). Characteristics and goals of family owneroperated businesses in the rural tourism and hospitality sector. Tourism Management, 21(6), 547-560.

Getz, D., Carlsen, J., Morrison, A. (2004). The Family Business in Tourism and Hospitality. Wallingford, Oxon, UK. Cambridge, Mass, USA: CABI Pub.

Getz, D., Carlsen, J. (2005). Family business in tourism: state of the art. Annals of Tourism Research, 32(1), $237-258$. Doi 10.1016/j.annals.2004.07.006.

Harveston, P. D., Davis, P. S., Lyden, J. A. (1997, December). Succession Planning in family business: the impact of owner gender. Family Business Review, 10(4); 373-396. Doi: 10.1111/j.1741-6248.1997.00373.x.

Hvolková, L. (2013). Realizácia sociálne zodpovedných investícií v slovenských podnikoch. Aktuálne problémy podnikovej sféry 2013. Zborník vedeckých prác. Bratislava: EKONÓM.

Chen, S. C., Elston, J. A. (2013). Enterpreneurial motives and characteristics: An analysis of small restaurant owners. International Journal of Hospitality Management, 35, 294-305.

Klementová, V. (2008). Selected problems of obligatory insurance contributions burden of labour in connection to Lisbon Strategy implementation. Perspective Tudományos és kulturális folyóirat, 13(14); 77-85. 
Kučerová, J., Marčeková, R., Nedelová, G. (2010). Wellness tourism in Slovakia. Moravian Geographical Reports, 18(3); 2-13.

Kučerová, J., Makovník, T. (2009). Regional Tourism Policy in Slovakia. E+M Ekonomie a Management, 12(1); 6-13.

Malachovský, A. (2012). Market strategies in Slovak and Austrian tourism. Current Issues of Tourism Research, 2(2), 39-48.

Mandl, I. (2008). Overview of Family Business Relevant Issues. Final Report. Vienna: Austrian Institute for SME Research. Retrieved from http:// ec.europa.eu/enterprise/policies/sme/files/craft/family_business/doc/ familybusiness_study_en.pdf.

Mandl, I., Obenaus, S. (2008). Overview of Family Business Relevant Issues, Country Fiche Austria. Vienna: Austrian Institute for SME Research. Retrieved from http://ec.europa.eu/enterprise/policies/sme/files/craft/ family_business/doc/familybusines_country_fiche_austria_en.pdf.

McCabe, H.M. (2012, June). Simple enough? Implementing a smooth client relation to reduce friction. Family Firm Institute, 8(7),1-4. Retrieved from http://ec.europa.eu/enterprise/ policies/sme/files/craft/family_ business/doc/familybusines_country_fiche_austria_en.pdf.

Pompurová, K. (2013). Atraktívnost'Slovenska ako ciel'ového miesta cestovného ruchu. Banská Bystrica: Univerzita Mateja Bela, Ekonomická fakulta.

Statistical Office of Slovak Republic. (2013). Indicators of Economic Development of the Slovak Republic. Available from Statistical Office of the Slovak Republic database.

\section{Abstrakt (in Polish)}

Głównym celem artykułu jest identyfikacja podstawowych ciężarów utrudniajqcych prowadzenie biznesu postrzeganych przez Słowackie firmy rodzinne jak również ocena ich perspektyw rozwoju biznesu rodzinnego na Słowacji. Artykuł analizuje podstawowe dane uzyskane w badaniu opinii przeprowadzonym za pomoca kwestionariuszy w 2013 roku. Postrzeganie środowiska biznesu oceniane jest według określonych wskaźników zewnętrznego środowiska biznesu (warunki prowadzenia działalności), które uzyskano na podstawie wyników pilotażowego badania przeprowadzonego w 2009 roku oraz badań z lat 2010/2011. Wyniki te określajq najżywiej dyskutowane tematy oraz ciężary utrudniajqce prowadzenie biznesu w słowackiej turystyce i hotelarstwie.

Słowa kluczowe: rodzinny biznes, hotelarstwo, środowisko biznesu, warunki prowadzenia działalności biznesowej. 